\title{
Therapy of Sialorrhea with Botulinum Neurotoxin
}

Wolfgang H. Jost · Tobias Bäumer · Rainer Laskawi · Jaroslaw Slawek •

Björn Spittau • Armin Steffen · Martin Winterholler · Ganesh Bavikatte

Received: August 9, 2019 / Published online: September 21, 2019

(C) The Author(s) 2019

\section{ABSTRACT}

Botulinum neurotoxin (BoNT) is considered the treatment of choice for various symptoms and diseases such as focal dystonia and focal spasticity. The effects of BoNT on the salivary glands have also been known for years, but their use was limited because of a lack of approval studies. Now the indication of sialorrhea is approved in some countries for incobotulinumtoxinA, such as the USA and Europe, and therapy could also become the treatment of choice. According to the pivotal study, a dose of 100 units of incobotulinumtoxinA, which is divided into the parotid and submandibular glands, is

Enhanced digital features To view enhanced digital features for this article go to https://doi.org/10.6084/ m9.figshare.9762407.

W. H. Jost (凶)

Parkinson-Klinik Ortenau, Wolfach, Germany

e-mail: W.Jost@parkinson-klinik.de

T. Bäumer

Paediatric and Adult Movement Disorders and

Neuropsychiatry, Institut of Neurogenetics,

University of Lübeck, Lübeck, Germany

R. Laskawi

ENT Department, University Medical Center, Göttingen, Germany

J. Slawek

Neurology Department, Medical University of

Gdansk, Gdańsk, Poland recommended. RimabotulinumtoxinB is approved in the USA only. To define the value of this therapy, we must consider anatomy, physiology, and available therapies. Therapy includes conservative measures such as functional dysphagia therapy, oral or transdermal application of anticholinergics, and, in selected cases, radiotherapy and surgical procedures. A combination of different approaches is optional. On the basis of the evidence and clinical experience, BoNT injections will be the first line of pharmacotherapy for chronic sialorrhea.

Keywords: Anticholinergics; Botulinum toxin; Drooling; Dysphagia; Sialorrhea

\section{B. Spittau}

Center for Transdisciplinary Neurosciences Rostock (CTNR), University of Rostock, Rostock, Germany

\section{A. Steffen}

Department for Otorhinolaryngology, University of Lübeck, UKSH, Lübeck, Germany

M. Winterholler

Krankenhaus Rummelsberg, Schwarzenbruck, Germany

G. Bavikatte

Walton Centre NHS Foundation Trust, Liverpool, UK 


\section{INTRODUCTION}

The indication range for botulinum toxin (BoNT) has continuously expanded over recent years, while many of the potential indications have not been followed up because the effort did not appear justified. For a long time this same caveat was held concerning sialorrhea even though the effect of the toxin in treating sialorrhea was well recognized as of the late 1990s, but approval studies were completely lacking up till then [1]. However, the data situation improved and approval was granted in Europe and the USA, which has led to new dynamics. Thus, the treatment for sialorrhea has been and will further be developing for the better. The aim of this manuscript is to provide an overview regarding sialorrhea and treatment options with special focus on BoNT injections. This article is based on previously conducted studies and does not contain any studies with human participants or animals performed by any of the authors.

\section{ANATOMICAL BASICS OF SALIVARY GLANDS}

The daily secretion of approximately 1-1.5 1 of saliva into the oral cavity is mainly ensured by the three paired salivary glands of the head. The parotid gland (glandula parotis) is the largest of all salivary glands with an irregular shape and an approximate weight of $20 \mathrm{~g}$. It usually extends from the inferior parts of the zygomatic arch to the anterior border of the sternocleidomastoid muscle and horizontally from the mastoid process to the masseter muscle (Fig. 1). Its secretion is transmitted through the parotid duct which breaks through the buccinator muscle and into the oral vestibule at the level of the second molars of the upper row of teeth [2]. The submandibular gland (glandula submandibularis) is located on the inner surface of the mandible below the mylohyoid line. The sublingual gland (glandula sublingualis) is embedded in the mucous membrane of the floor of the mouth and has, in addition to a main sublingual duct (ductus sublingualis major), several minor ducts that are located on both sides of the lingual frenulum in order to secrete into the oral cavity. On both sides, secretions are delivered into excretory submandibular ducts which drain together with the major sublingual ducts into small prominences on each side of the lingual frenulum called sublingual caruncles [3, 4].

The cellular composition of the individual salivary glands is just as characteristic as the secretions produced in each gland. The parotid gland produces a serous, protein-rich (amylase) secretion that accounts for about $25 \%$ of the total saliva and its major function is the breakdown of complex carbohydrates. The submandibular gland accounts for the largest volume fraction (approximately 70\%) of the total salivary secretion and is histologically characterized by the presence of serous and mucous acini which release enzyme-rich secretions promoting carbohydrate breakdown and mucin-rich secretions, respectively. As glycoproteins with lubricating properties, mucins constitute another important component of the secretion and support the lubricity of the chyme. The secretion of the predominantly mucous sublingual glands, which accounts for $5 \%$ of the saliva volume, is particularly rich in mucins [5]. In addition to the breakdown of carbohydrates and increasing the lubricity of the chyme, the saliva in general is very important for dissolving flavors that can be perceived via the taste buds of the tongue and the tongue bottom [6]. Another important function of saliva is the continuous irrigation of the surfaces of the oral cavity and, thereby, the associated growth control of bacterial biofilms. A reduction in salivary secretion often results in increased growth of bacterial cultures, which can lead to recurrent infections and erosions of the gingiva and teeth [7].

Salivary secretion is regulated by the autonomic nervous system. All salivary glands are supplied with sympathetic nerve fibers as well as parasympathetic nerve endings. While postganglionic sympathetic fibers from the superior cervical ganglion of the sympathetic trunk (truncus sympathicus) enter the cranium via the carotid plexus and attach themselves to sensitive branches of the trigeminal nerve $(\mathrm{X})$ to reach the respective glands, the 


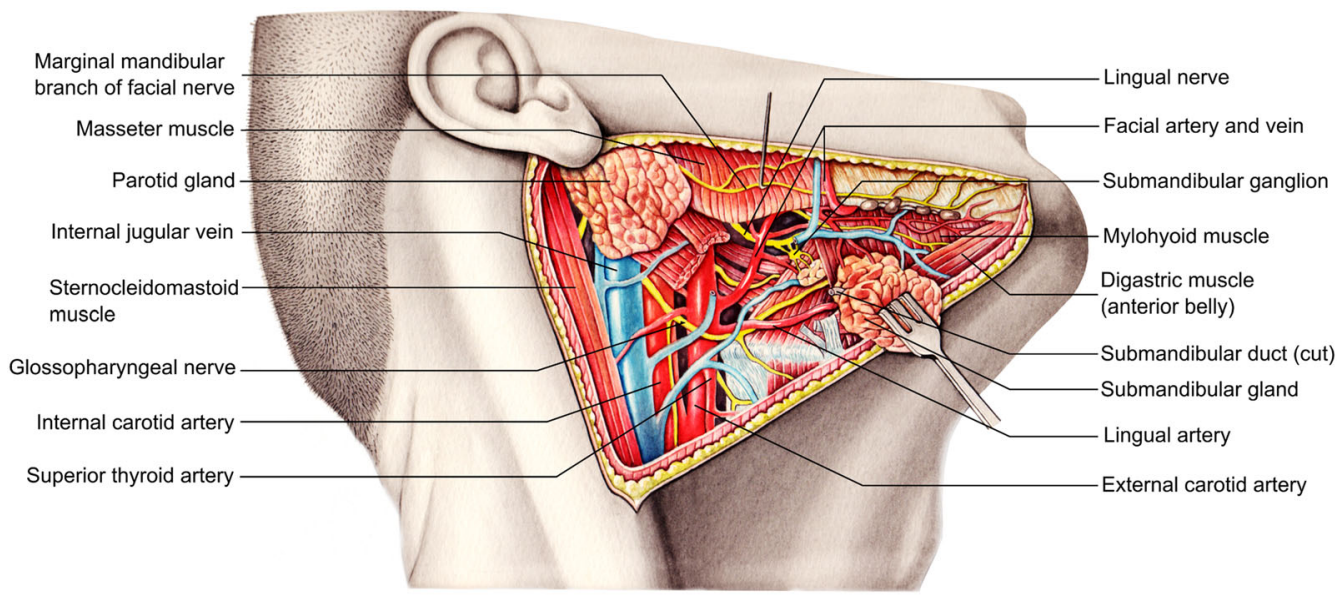

Fig. 1 Anatomy of the main salivary glands

parasympathetic supply of the salivary glands takes place via the nervus intermedius of the facial nerve (VII) as well as parasympathetic branches of the glossopharyngeal nerve (IX). For the parasympathetic supply of the sublingual gland and the submandibular gland, the chorda tympani as a vegetative branch of the facial nerve (VII) with preganglionic fibers from the superior salivary nucleus joins the lingual nerve (V3) to reach the parasympathetic submandibular ganglion close to the submandibular gland. Synapsing to the second parasympathetic neuron takes place there, and postganglionic fibers together with sympathetic fibers reach the sublingual and submandibular glands. The parasympathetic supply of the parotid gland is facilitated by preganglionic fibers from the inferior salivary nucleus via the lesser petrosal nerve of the glossopharyngeal nerve (IX). These fibers synapse in the otic ganglion located underneath the oval foramen of the skull base from where they emerge as postganlionic fibers to attach themselves via a communicating branch to the auriculotemporal nerve (mandibular nerve, V3). Via another anastomosis with the facial nerve (VII) the parasympathetic fibers finally reach the parenchyma of the parotid gland to stimulate saliva secretion. The course of parasympathetic fibers involving several nerve branches to innervate the parotid gland is often referred to as Jacobson anastomosis [2-4].

\section{VARIOUS CAUSES OF SIALORRHEA}

The constant secretion of saliva and the subsequent swallowing of saliva require a coordinated series of orofacial sensory and motor systems as well as the regulated act of swallowing itself. This act must be modulated dependent on respiration, as swallowing a bolus always involves a synchronous short closure of the respiratory tract for protection against aspiration. For this reason, deficient coordination in the secretion of saliva in the mouth during the first years of life is viewed as an indication of the degree of sensory-motor maturity; a continuation beyond the fourth year of life is taken as pathological $[8,9]$.

In adulthood, disturbances in the finer coordination of neuronal and muscular processes occur in neurological deficits such as in cerebral palsy, or subsequent to brain trauma or brain infarction as well as in the course of neurodegenerative diseases. Differential diagnosis should also take the possibility of achalasia into consideration, which in turn then necessitates gastroenterological diagnostics. Other causes include anatomical defects pursuant to accidents or in various therapeutic stages for head and neck carcinoma, whereby resection or postoperative scar formation induces anatomical deformities which inhibit a complete closure on the laryngeal inlet, although neuronal coordination is properly functioning. A genuine hypersalivation 
resulting from increased salivation is seen as a side effect of drugs, as especially occurs in the treatment with atypical antipsychotics, e.g., clozapine [10]. In addition, dopamine agonists can induce hypersalivation by provoking Parkinson-like symptoms or parkinsonoid with reduced frequency of swallowing.

The patients' degree of subjective impairment from the clinical symptoms is of course decisive. But in addition the possibility of a silent aspiration of saliva should always be kept in mind as well. Not unusually, further details have to be obtained by interviewing family members or nursing personnel. Relevant contributing factors include the general level of activity, the body position, and the prevailing mood. Special attention should be given to the intellectual abilities of children with sialorrhea as these abilities are often underestimated because of the external appearance of the children. For monitoring therapeutic progress several standardized interview questionnaires have been shown to be suitable, e.g., the Teacher Drooling Scale [11] and the Drooling Frequency and Severity Scale (DFSS) from Crysdale and White [12] and ThomasStonell and Greenberg [13]. These questionnaires allow for estimating the intensity of symptoms as well as the frequency of the sialorrhea, which is of course particularly needed in monitoring the course of therapy.

Exact quantitative ascertainments of the amount of saliva have clear methodical shortcomings and disadvantages and thus have not yet gained much pragmatic relevance for clinical practice. With that caveat, we could mention chin cups, measurements for dampness in bibs and shirts [14], or weighing rolls of cotton cloth [15].

During clinical examination particular attention should be given not only to the proper functioning of facial, lingual, and soft palate motor activity but especially to muscle tone, head posturing, and the potential anatomical causes for any oral respiration. Tongue thrusting, which is considered pathological, should be looked for. Even but slight malpositioning of the teeth or occlusal disturbances (and especially the frequent occurrence in these patients of anterior open bites) can overtax orofacial motor competency. This brief discussion already shows that the initial assessment should be done as early as possible and through a multidisciplinary team with the goal of clarifying the underlying condition and the pathophysiology of the sialorrhea $[16,17]$.

Given a tentative diagnosis of (micro)aspiration, or when respiratory problems occur while eating or meals take overproportionate amounts of time or when pneumonia occurs frequently, patients with sialorrhea should undergo a timely screening for their swallowing ability [18] and an examination by the swallowing therapist, phoniatric services, or ENT specialists, including endoscopic examination of swallowing $[19,20]$. Both insufficient passage in the region of the mouth (e.g., the premature slippage of a bolus into the pharynx: "leaking") and disturbances in the pharyngeal phase of swallowing (as when closure of the aditus laryngis occurs with intra- and post-deglutitive aspiration) call for endoscopic evaluation of swallowing via fiber-optic endoscopes (FEES), which today constitute an indispensable standard examination [21] and which have become well established in view of their good implementation options in conscious patients and their especially high degree of explanatory power for the act of swallowing in clinical everyday contexts. These diagnostics are also available for work with children [22-25].

With a tentative diagnosis of esophageal passage disorders, $\mathrm{x}$-ray video fluoroscopy of swallowing should be performed [26]. This diagnostic tool registers anatomical as well as functional esophageal constriction. With this method aspiration which with endoscopic techniques would otherwise be undetectable ("whiteout") can be documented. Both these diagnostic methods are dependent on team collaboration. This seriously delimits the diagnostic usefulness of such measures, whereas real-time MR sequences may prove themselves appropriate in time as a promising development for the future $[27,28]$.

\section{EXERCISE THERAPY FOR SWALLOWING DISORDERS}

A basic intervention involves therapeutic measures for swallowing, in particular when 
sialorrhea is only one partial aspect of dysphagia, albeit an all-apparent one. A functional dysphagia therapy (FDT) [29], when targeted at the pathophysiological causation, takes the frequent occurrence of aspiration into consideration. The effectivity of FDT for reducing the risk of aspiration has been adequately demonstrated [30, 31]. For treating dysphagia as a consequence of brain lesioning, we assume that therapy induces a functional reorganization of the intact motor cortex [32]. Analogous to the basic principles of rehabilitation, FDT can be partitioned into the main categories of restitution, compensation, and adaptation. In this way the reduction of pathological reflex activity or the stimulation of the swallowing reflex is seen as a stimulus paving the way for restitution. For compensation, alterations in head posture have to be performed for modifying bolus passage and for partially complicated swallowing techniques. And, finally, adaptation entails mainly dietary adjustments to modify, for example, the bolus volume and the consistency of the food so as to influence bolus transport. The effectivity of these measures, but most importantly head posturing, can be fully managed under FEES.

In children, when insufficient orofacial muscle tone is seen as the cause, the focus of attention is placed on training methods of selfperception for subsequently developing an orderly process of swallowing in the orofacial area. Methods which make use of technological support such as kinesio-taping have been successful here [33].

In everyday life, however, these methods are frequently severely limited because of lack of cooperation skills in the patients, the frequent slow-evolving dynamics in the symptoms themselves, and the local unavailability of therapeutic services.

\section{ORTHODONTIC MEASURES}

An orthodontic approach to therapy is meaningful in cases of dysgnathia in order to remedy a disturbing malocclusion as a cofactor for sialorrhea.
Palatal stimulation plates as suggested by Castillo-Morales help to promote adequate lip closure (appliances such as the "mouth vestibular brace") [34].

Stimulation of the tongue by means of elements fixated to the palatal plate can effectively reduce sialorrhea by increasing mouth closure and improving basal positioning of the tongue, especially when performed in a multimodal approach [35].

\section{MEDICAL INTERVENTIONS BESIDE BOTULINUM NEUROTOXIN}

Medical treatment for hypersalivation aims at inhibiting salivary secretion through anticholinergic/antagonistic drugs. Essentially, these are atropine [36-38], scopolamine [39], and glycopyrrolate [40-49]; glycopyrrolate has the advantage of inducing weaker central nervous side effects. For children and adolescents in Germany a formula, Sialanar ${ }^{\circledR}(320 \mu \mathrm{g} / \mathrm{ml}$ glycopyrronium), became available for prescription since the spring 2018 because randomized controlled studies found a positive effect with a favorable side effect profile $[50,51]$. This is a novel occurrence, as all other preparations are responsible for a specific disclosure when under off-label use and this adversely affects the possibility of cost coverage by the health insurance companies.

\section{SURGICAL MEASURES}

Surgical interventions on the salivary glands include particularly relocating the submandibular duct and various forms of duct interruption and ligation of the large salivary glands. According to the studies published to date $[12,52-60]$ these interventions are successful. Because in relocating the ducts of the salivary glands of the submandibular glands in particular the non-stimulated basal secretion of saliva is directed right into the hypopharynx, the risk of aspiration is considerably increased and must be evaluated beforehand. In cases when opening the upper esophageal sphincter is disturbed or if injections of botulinum toxin 
lead to repeated complaints, cricopharyngeal myotomy can be considered [61, 62].

\section{EXTERNAL RADIOTHERAPY OF SALIVARY GLANDS}

The effectivity of external radiotherapy has been described (in a partially controlled approach [63-69]) for sialorrhea seen in various neurological diseases. Subsequent to unsuccessful treatment with botulinum toxin, radiation can reduce sialorrhea [70] and, vice versa, post-radiogenic sialorrhea can be reduced by injections of BoNT [71]. This has been demonstrated for additional indications as well, e.g., in the treatment of salivary fistula after parotidectomy [72]. Although the basic as well as the long-term effectivity is in no way disputed, we cannot ignore the potential adverse effects and the carcinogenic potentials, discussed later.

\section{BOTULINUM TOXIN IN TREATMENT OF SIALORRHEA}

BoNT represents an alternative form of treatment for the salivary glands compared with others, namely systemic pharmacological treatments, surgery, and radiation.

Botulinum toxins are high molecular weight protein complexes consisting of the neurotoxin and the coat proteins. The two chains of the neurotoxin are attached to each other through a disulfide bridge. The lighter neurotoxic section is a zinc-containing endopeptidase. The heavy chain connects to the presynaptic membrane of cholinergic terminal axons and ensures their uptake into the protein complex, whereby the lighter protein then attaches to proteins of the exocytosis complex (e.g., synaptosome-associated protein 25 , SNAP-25) which inhibits the release of acetylcholine.

A distinction is made between the serotypes A to $\mathrm{H}$, two of which (namely A and B) are used for medical purposes.

BoNT blocks presynaptically the release of acetylcholine in parasympathetic (and sympathetic cholinergic) ganglia [73]. Similar to cases involving the terminal motor axon, the effect lasts 3-4 months and is reconstituted by means of re-innervation subsequent to degeneration of the terminal axon. Through intraglandular injection of BoNT into the larger salivary glands, a blockade occurs in the neurogenic (parasympathetic) control of salivary secretion which persists for a good quarter of a year. Reconstitution is effected by the re-innervation. First successful treatments here were reported by Bushara (1997), Bhatia (1999), and Jost (1999) [74-76].

The efficacy of BoNT treatment with serotype B (rimabotulinumtoxinB) has also been studied, as well as the effect of various BoNT-A preparations (abobotulinumtoxinA, incobotulinumtoxinA, onabotulinumtoxinA). The effects of all the toxins have been reproduced in case studies as well as in controlled studies, some of which were placebo controlled [1, 76-81].

The study populations consisted of patients with Parkinson syndromes, amyotrophic lateral sclerosis, infantile cerebral damage, head and neck tumors/otorhinolaryngological tumors, tracheal cannulas and artificial respiration, dysphagia without various causation, and hypersalivation induced by their medication [10, 80, 82-85].

Evidence of efficacy was provided in almost all the studies through quantitative measurement of the saliva production, whereby mostly the exact weight was determined for the standard cotton pads used in dentistry, which take up newly secreted saliva within a set time limit. In almost all these studies again, analysis was performed for the subjective feeling of saliva production and consequent quality of life in the patients themselves, occasionally corroborated by their relatives' or caretakers' observations [79-83, 86-94] (Table 1).

There is controversy as to whether the intensity and duration of saliva secretion after treatment with BoNT of the serotype B are superior to those after serotype A. In spite of the good current study situation after reliable shortterm use, a clinically relevant tendency seems to be the case for antibody production against the toxin with serotype B $[87,95,96]$. 
Table 1 Randomized controlled studies on therapy for sialorrhea with BoNT (listing only first author, in alphabetic order)

\begin{tabular}{|c|c|c|c|c|c|}
\hline Author & $\begin{array}{l}\text { Patients } \\
(n)\end{array}$ & and methods & Results & $\begin{array}{l}\text { Diagnoses } \\
\text { toxin }\end{array}$ & Undesired effects \\
\hline $\begin{array}{l}\text { Chinnapongse } \\
\text { et al. }[88]\end{array}$ & $\begin{array}{l}54 \\
\text { PC DB } \\
\text { RCT }\end{array}$ & $\begin{array}{l}\text { Follow-up } 20 \text { weeks } \\
\text { DFSS } \\
\text { Saliva quantitative } \\
\text { assessment of } \\
\text { sialorrhea }\end{array}$ & $\begin{array}{l}\text { Significant improvement } \\
\text { from 4th to 16th } \\
\text { week, dose dependent }\end{array}$ & $\begin{array}{l}\text { PD } \\
\text { Rima-B 1500, } \\
\text { 2500, } 3500 \mathrm{U}, \\
\text { placebo }\end{array}$ & $\begin{array}{l}\text { Gastrointestinal } \mathrm{AE} \\
\text { in } 31 \% \text { vs } 7 \% \text { of } \\
\text { controls, mainly } \\
\text { dry mouth }\end{array}$ \\
\hline $\begin{array}{l}\text { Guidubaldi et al. } \\
\text { [89] }\end{array}$ & $\begin{array}{l}14 \\
\text { DB RCT } \\
\text { Crossover }\end{array}$ & $\begin{array}{l}\text { Saliva flow } \\
\text { Subjective: interview }\end{array}$ & $\begin{array}{l}\text { Rima-B and Dysport } \\
\text { effective, latency lower } \\
\text { for Rima-B }\end{array}$ & $\begin{array}{l}\text { ALS, Parkinson } \\
2500 \text { U Rima-B } \\
250 \text { U Abo-A }\end{array}$ & Viscous saliva \\
\hline $\begin{array}{l}\text { Jackson et al. } \\
{[90]}\end{array}$ & $\begin{array}{l}20 \\
\text { PC DB } \\
\text { RCT }\end{array}$ & Global impression scale & $\begin{array}{l}\text { GIS } 72 \% \text { vs } 38 \% \\
\text { (placebo) positive } \\
50 \%>12 \text { weeks effect }\end{array}$ & $\begin{array}{l}\text { ALS } \\
2500 \text { U Rima-B }\end{array}$ & - \\
\hline Jost et al. [1] & $\begin{array}{l}184 \\
\text { DB PC } \\
\text { RCT }\end{array}$ & $\begin{array}{l}\text { Global impression } \\
\text { Quantity of salivation }\end{array}$ & $\begin{array}{l}\text { Significant reduction in } \\
\text { salivary secretion over } \\
12 \text { weeks, } 100 \mathrm{U} \text { more } \\
\text { effective }\end{array}$ & $\begin{array}{l}\text { Various } \\
\text { diagnoses, } \\
70.7 \% \mathrm{PD} \\
\text { Inco-A } 75 \text { and } \\
100 \mathrm{U}\end{array}$ & Dry mouth \\
\hline $\begin{array}{l}\text { Lagalla et al. } \\
\text { [91] }\end{array}$ & $\begin{array}{l}32 \\
\text { DB PC } \\
\text { RCT }\end{array}$ & $\begin{array}{l}\text { Subjective impression of } \\
\text { drooling (VAS), } \\
\text { drooling frequency, } \\
\text { social disability }\end{array}$ & $\begin{array}{l}\text { Significant reduction of } \\
\text { sialorrhea after } \\
4 \text { weeks }\end{array}$ & $\begin{array}{l}\text { PD } \\
\text { Ona-A } \\
100 \mathrm{MU}\end{array}$ & - \\
\hline $\begin{array}{l}\text { Lagalla et al. } \\
\text { [92] }\end{array}$ & 36 & $\begin{array}{l}\text { Drooling severity scale, } \\
\text { GIS, VAS social } \\
\text { distress }\end{array}$ & $\begin{array}{l}\text { Significant improvement } \\
\text { Effect duration } \\
19.2 \text { weeks }\end{array}$ & $\begin{array}{l}\text { PD } \\
\text { Rima-B } 4000 \mathrm{U}\end{array}$ & Dry mouth \\
\hline Lipp et al. [93] & $\begin{array}{l}32 \\
\text { DB PC } \\
\text { RCT }\end{array}$ & $\begin{array}{l}\text { Global impression } \\
\text { Quantitative assessment } \\
\text { of drooling }\end{array}$ & & $\begin{array}{l}\text { Various } \\
\text { diagnoses, } \\
\text { Abo-A 18.75, } \\
\text { 37.5, } 75 \mathrm{U}\end{array}$ & None \\
\hline $\begin{array}{l}\text { Mancini et al. } \\
\text { [80] }\end{array}$ & 20 & $\begin{array}{l}\text { DFSS } \\
\text { salivation }\end{array}$ & $\begin{array}{l}\text { Significant reduction in } \\
\text { drooling } \\
\text { for }>3 \text { months }\end{array}$ & $\begin{array}{l}20 \mathrm{PD} \\
\text { Abo-A } 450 \mathrm{U}\end{array}$ & None \\
\hline $\begin{array}{l}\text { Mazlan et al. } \\
{[86]}\end{array}$ & $\begin{array}{l}30 \\
\text { PC DB } \\
\text { RCT }\end{array}$ & $\begin{array}{l}\text { Reduction in salivation } \\
\text { after } 2,6,12, \\
24 \text { weeks } \\
\text { DFSS }\end{array}$ & $\begin{array}{l}\text { Best effect with } 200 \mathrm{U} \\
\text { Abo-A, up to } \\
24 \text { weeks }\end{array}$ & $\begin{array}{l}\text { Neurogenic } \\
\text { sialorrhea } \\
\text { Abo-A 50, 100, } \\
200 \mathrm{U}\end{array}$ & $\begin{array}{l}\text { Viscous (thick) } \\
\text { saliva pain during } \\
\text { injection }\end{array}$ \\
\hline
\end{tabular}


Table 1 continued

\begin{tabular}{|c|c|c|c|c|c|}
\hline Author & $\begin{array}{l}\text { Patients } \\
(n)\end{array}$ & Criteria and methods & Results & $\begin{array}{l}\text { Diagnoses } \\
\text { toxin }\end{array}$ & Undesired effects \\
\hline $\begin{array}{l}\text { Narayanaswami } \\
\text { et al. [82] }\end{array}$ & $\begin{array}{l}10 \\
\text { DB PC } \\
\text { RCT } \\
\text { Crossover }\end{array}$ & $\begin{array}{l}\text { DFSS } \\
\text { Quantitative assessment } \\
\text { of saliva }\end{array}$ & No significant effect & $\begin{array}{l}\text { PD } \\
\text { Inco-A } 100 \mathrm{U}\end{array}$ & $\begin{array}{l}\text { Tongue control, } \\
\text { chewing weakness, } \\
\text { viscous saliva }\end{array}$ \\
\hline Ondo et al. [87] & 16 & $\begin{array}{l}\text { Assessment of drooling } \\
\text { VAS; DFSS }\end{array}$ & $\begin{array}{l}\text { Significant improvement } \\
\text { in VAS and DFSS }\end{array}$ & $\begin{array}{l}\text { PD } \\
\text { Rima-B } 2500 \mathrm{U}\end{array}$ & - \\
\hline Reid et al. [94] & $\begin{array}{l}48 \\
\text { RCT } \\
\text { Control } \\
\text { group }\end{array}$ & Drooling impact scale & $\begin{array}{l}\text { Significant improvement } \\
\text { Up to } 6 \text { months }\end{array}$ & $\begin{array}{l}\text { Developmental } \\
\text { disorder } \\
\text { Ona-A } 100 \mathrm{U}\end{array}$ & - \\
\hline $\begin{array}{l}\text { Steinlechner } \\
\text { et al. [107] }\end{array}$ & $\begin{array}{l}9 \\
\text { DB PC }\end{array}$ & Global impression & $\begin{array}{l}\text { Reduction of sialorrhea } \\
\text { for } 8-16 \text { weeks }\end{array}$ & $\begin{array}{l}\text { Neuroleptic } \\
\text { therapy, PD } \\
\text { Rima-B }\end{array}$ & Dry mouth \\
\hline Weikamp [69] & $\begin{array}{l}20 \\
\text { RCT }\end{array}$ & $\begin{array}{c}\text { Global impression and } \\
\text { patients' satisfaction }\end{array}$ & $\begin{array}{l}\text { Irradiation of the } \\
\text { salivary glands and } \\
\text { Ona-A with equal } \\
\text { effects }\end{array}$ & $\begin{array}{l}\text { ALS } \\
\text { Ona-A vs } \\
\text { irradiation }\end{array}$ & $\begin{array}{l}\text { More local adverse } \\
\text { effects with } \\
\text { irradiation }\end{array}$ \\
\hline
\end{tabular}

$D B$ double blind, $P C$ placebo controlled, $R C T$ randomized controlled study, $V A S$ visual analogue scale, $D F S S$ drooling frequency and severity scale, $A L S$ amyotrophic lateral sclerosis, Abo-A abobotulinumtoxin type $\mathrm{A}$ (Dysport ${ }^{\circledR}$ ), Inco- $A$ incobotulinumtoxin type $\mathrm{A}\left(\mathrm{Xeomin}^{\circledR}\right)$, Ona-A onabotulinumtoxin type $\mathrm{A}$ (Botox $\left.{ }^{\circledR}\right)$, Rima-B rimabotulinomtoxin type $\mathrm{B}$ $\left(\right.$ Neurobloc $\left.^{\circledR}\right)$

Injections were generally done transcutaneously directly into the salivary glands.

Trials with transductal and intraoral injection techniques were later abandoned because of intolerable side effects [97].

So as to reduce saliva secretion under conditions of both resting and stimulation, the majority of the authors consider synchronous injection into the submandibular gland and the parotid gland to be essential. Sonographic control of the injection is particularly advisable when treating the submandibular gland, as difficulty in swallowing as a result of unintended diffusion into the adjacent muscles can thus be avoided [98]. Standardized documentation forms can be used for more proficient comparison and control of the therapy.

In July 2018 incobotulinumtoxinA was approved for the treatment of chronic sialorrhea in adults without restrictions, independent of the underlying disease. The recommended treatment dosage is 100 units, with 30 units given to each of the two parotid glands and 20 units to the two submandibular glands; a possible repetition can be undertaken after 16 weeks. As of October 2014 an international randomized, placebo-controlled phase III approval study is also being done in patients aged 2-17 with incobotulinumtoxinA; the data have not yet been released. 
Now that incobotulinumtoxinA has just been approved (as of May 2019) for the treatment of chronic sialorrhea due to neurological diseases in adults by the EMA (European Medicines Agency) as well, the drug already approved for this indication, incobotulinumtoxinA, should be applied here at present, for both medical and insurance reasons. From an economic point of view, of course, the relatively high costs of BoNT therapy have to be considered, with corresponding studies missing.

Approval was based on the SIAXI (Sialorrhea in Adults Xeomin Investigation) study [1], a randomized, placebo-controlled double blind study in which two groups of 74 patients were given either $75 \mathrm{MU}$ or $100 \mathrm{MU}$ incobotulinumtoxinA, while 36 received a placebo. The patients suffered mainly from Parkinson's disease $(70.7 \%)$, atypical Parkinson syndromes, stroke, and traumatic brain injury. In each case, $60 \%$ of the dose was injected into the parotid glands and $40 \%$ into the submandibular glands. In the 16 weeks of the follow-up phase, subjective parameters were documented as well as the "global impression of change scale" and the unstimulated amount of saliva secretion over a predefined time period as objective measure.

Up to the 12th week significant improvement was found in all parameters, up to 16 weeks in both co-primary parameters. Side effects (in particular a dry mouth) were observed in $8-9 \%$ of all patients, but in the placebo group as well. Serious side effects were not observed in any cases; $4.1 \%$ of the patients treated with $100 \mathrm{U}$ of incobotulinumtoxin reported experiencing transient dysphagia [1].

Approval was granted for the higher of the two dosages $(100 \mathrm{MU})$ because the effect held longer and was stronger and the safety profile was identical. Interestingly, a clear advantage for injecting under sonographic control (which the examiners could opt for voluntarily) could not be seen.

During the 48-week extension phase of the study [99], which included three further injection cycles, persistent efficacy was seen, and tolerability and therapy adherence remained at the same high level (141/184 patients). Mean uSFR (unstimulated salivary flow rate) decreased consistently with repeated
incobotulinumtoxinA $75 \mathrm{U}$ and $100 \mathrm{U}$ treatment. Subjects' GICS (Global Impression of Change Scale), DFSS (Drooling Frequency and Severity Scale), and mROMP (modified Radboud Oral Motor Inventory for Parkinson's Disease) drooling scores also improved at all assessments. The most common treatment-related AEs during the extension period were dry mouth $(4.4 \%$ and $11.1 \%)$ and dysphagia $(1.5 \%$ and $4.2 \%)$.

It is precisely this final approval for incobotulinumtoxin that affirms the decision by physicians experienced in using botulinum toxin over the last two decades for making use of the treatment "out of label". Considering the primacy in the medical guidelines of first exploiting other treatment options (therapy for swallowing, mouth hygiene, optimized Parkinson-specific medication), BoNT represents a useful and reliable enrichment in the treatment options for sialorrhea.

In August 2019 the US Food and Drug Administration (FDA) approved rimabotulinumtoxinB for chronic sialorrhea in adults. The recommended dose is $500-1500$ units per parotid gland and 250 units per submandibular gland (total dose 1500-3500 units). Dry mouth and dysphagia were stated to be frequent side effects.

\section{ULTRASOUND-GUIDED INJECTION FOR APPLICATION OF BOTULINUM TOXIN INTO SALIVARY GLANDS}

When treating hypersalivation with botulinumtoxin, the injection is usually applied to the parotid and submandibular glands. The volume of the parotid glands is bigger compared to the submandimular glands [100, 101]. Therefore typically the portion of botulinumtoxin injected is bigger for the parotid gland. This is also reflected in the recommendation of the approval of incobotulinumtoxin for the treatment of hypersalivation in the USA and Europe (some countries recommend the use of ultrasound, in other countries it is a condition).

In order to safely inject the salivary glands and in particular to artificially treat non-adjacent structures such as the muscles of the floor 
of the mouth, the question arises whether an ultrasound-guided injection is sensible compared to an injection according to anatomical landmarks. A direct comparison of the two methods for patients with Parkinson's disease is available for 15 patients with parotid gland injections and it shows a superiority of ultrasound-guided injection [98]. The SIAXI study [1], in which about half of the patients were injected into both parotid and submandibular glands by means of anatomical landmarks and half by means of ultrasound-guided injection technique, showed no clear difference in the therapeutic response of the two groups, with only the primary outcome parameter showing little superiority. Although this might indicate that an injection according to anatomical landmarks is also effective, a statement about the hit rates is only possible to a very limited extent because injections were consistently guided by ultrasound or anatomical landmarks at the investigators' discretion and the landmarks used in the study are not mentioned [1].

The accuracy of an anatomical landmarkoriented and an ultrasound-guided injection into the parotid and submandibular glands was investigated in a study with two different injectors on six body donors. A significant and significantly increased hit rate of the ultrasound-guided injection for the elbow submandibularis was found (50\% versus $92 \%$ ). For the parotid glands, this difference was not significant (79\% versus 96\%) [102] in favor of the ultrasound-guided injection technique. The reason for the high error rate, especially for the glandula submandibularis, is most likely the variance of the size of the gland, which is given as 1.6 to $15 \mathrm{ml}$ [101]. Another reason may be the deviation of the location of the gland from the expected location. Particularly in older people, the submandibular glands are occasionally more distant from the mandible. While the variance of the volume of the parotid gland is also high, it is fixed in the region of the jaw angle. The submandibular glands should be injected with knowledge of the anatomy of the glands of the individual patient; this is best done by ultrasound control. Therefore, ultrasound-guided injection of BoNT into the salivary glands for the treatment of hypersalivation is recommended in the AWMF (Association of Scientific Medical Societies in Germany) guidelines for the treatment of hypersalivation as follows: "Sonographically controlled injection of botulinum toxin into the large salivary glands can be recommended as an effective and safe form of treatment with long-lasting salivary reduction for a wide range of ages and diseases" [103].

\section{PRACTICAL INJECTION PROCEDURE}

The technical requirements of the ultrasonic device for the representation of the salivary glands are not too high. It is recommended to use a linear transducer (from $7 \mathrm{MHz}$ ), which is also used for vascular ultrasound diagnostics.

To locate the gland in ultrasound, it is advisable to place the transducer and the mandibular angle as shown in Fig. 2 and then adjust the position of the transducer to find the maximum of extent of the gland. For the parotid gland the point lies in the middle between the tragus and the jaw angle and for the submandibular gland it lies one finger width below the mandibular bone and in the distal third between the jaw angle and chin apex. The glands contrast clearly with the surrounding tissue because of their homogeneous internal echo structure and clear demarcation. The ultrasound probe should now be placed centrally over the gland to be injected. The injection can take place in "in plane" (the needle is guided in the longitudinal axis of the probe) or in "off plane" (to the transverse axis of the probe). Basically, the probe can be aligned horizontally or vertically during the injection.

In the case of injections at one site, this is usually the middle of the gland and not near to a salivary duct. In the case of several injections (usually not more than two to three), the injection points are distributed over the gland accordingly, e.g., around the ear lobule to anterior and/or posterior to the ear lobule.

The anatomical variability with regard to the exact position of the parotid glands is low and, in our experience, the recommended injection point according to the landmark positions corresponds quite well to the optimal point 

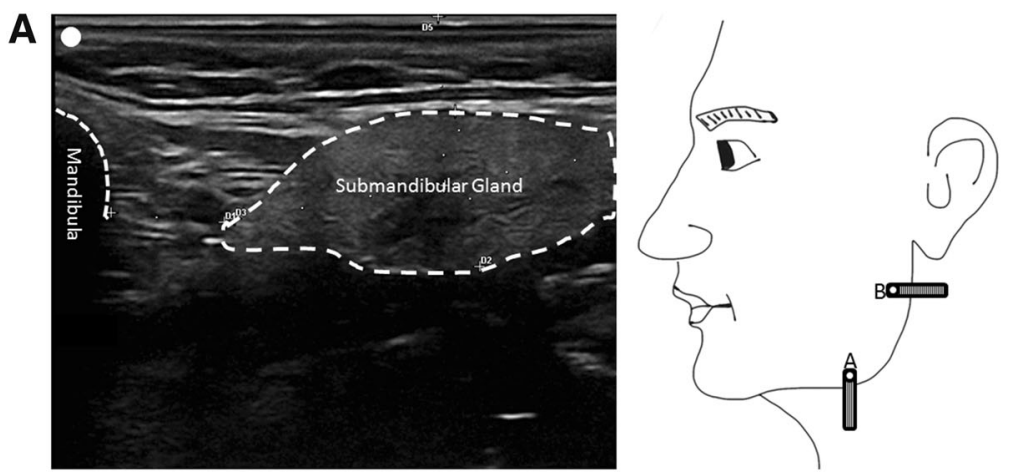

B

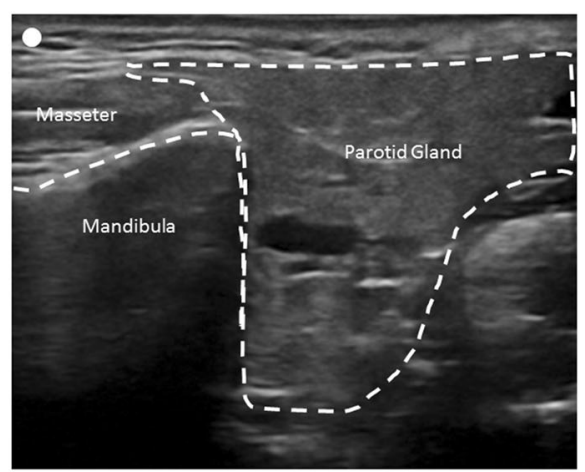

Fig. 2 Sonography of the main salivary glands

identified by ultrasound [102, 104], while other proposed landmarks do not fit well with the position identified by ultrasound [105].

The recommended injection point for the injection of the submandibular glands according to anatomical landmarks [104, 105] often does not correspond to the point identified by ultrasound. As shown above, there is often no gland at the site or it is very thin at this site, making it very difficult to place an injection there without visual control [102]. Therefore, the authors recommend the injection of botulinum toxin into the salivary glands, especially the submandibular glands, under sonographic control.

\section{RECOMMENDATIONS}

Sialorrhea is a clinically relevant problem in which the current treatment options have only limited success. With incobotulinumtoxinA we have for the first time an approved drug for adults, which means that the therapy may be considered the treatment of choice once the conservative measures have been exhausted. In accordance with the approval, it is recommended to inject 100 units of incobotulinumtoxinA dissolved in $2 \mathrm{ml}$ saline, distributed in the parotid and submandibular glands, if possible with ultrasound control. In August 2019 rimabotulinumtoxinB was approved in the USA (1500-3000 units). More studies with larger samples and longer follow-up periods are desirable to confirm the recent data [106].

\section{ACKNOWLEDGEMENTS}

Funding. No funding or sponsorship was received for this manuscript or publication of this article.

Authorship. All named authors meet the International Committee of Medical Journal Editors (ICMJE) criteria for authorship for this article, take responsibility for the integrity of the work as a whole, and have given their approval for this version to be published.

Disclosures. Wolfgang H. Jost is a consultant and/or speaker for the various BoNT manufacturers. Tobias Bäumer is a consultant and/or speaker for the various BoNT manufacturers. Rainer Laskawi is a consultant and/or speaker for the various BoNT manufacturers. Jaroslaw Slawek is a consultant and/or speaker for the various BoNT manufacturers. Armin Steffen is a consultant and/or speaker for the various BoNT manufacturers. Martin Winterholler is a consultant and/or speaker for the various BoNT manufacturers. Ganesh Bavikatte is a consultant and/or speaker for the various BoNT manufacturers. Björn Spittau has nothing to disclose.

Compliance with Ethics Guidelines. This article is based on previously conducted studies and does not contain any studies with human participants or animals performed by any of the authors. 
Data Availability. Data sharing is not applicable to this article as no datasets were generated or analyzed during the current study.

Open Access. This article is distributed under the terms of the Creative Commons Attribution-NonCommercial 4.0 International License (http://creativecommons.org/licenses/ by-nc/4.0/), which permits any noncommercial use, distribution, and reproduction in any medium, provided you give appropriate credit to the original author(s) and the source, provide a link to the Creative Commons license, and indicate if changes were made.

\section{REFERENCES}

1. Jost WH, Friedman A, Michel O, et al. SIAXI: placebo-controlled, randomized, double-blind study of incobotulinumtoxinA for sialorrhea. Neurology. 2019;92:e1982-91.

2. Kochhar A, Larian B, Azizzadeh B. Facial nerve and parotid gland anatomy. Otolaryngol Clin N Am. 2016;49:273-84.

3. Pedersen AML, Sørensen CE, Proctor GB, Carpenter GH, Ekström J. Salivary secretion in health and disease. J Oral Rehabil. 2018;45:730-46.

4. Proctor GB, Carpenter GH. Salivary secretion: mechanism and neural regulation. Monogr Oral Sci. 2014;24:14-29.

5. Holmberg KV, Hoffman MP. Anatomy, biogenesis and regeneration of salivary glands. Monogr Oral Sci. 2014;24:1-13.

6. Matsuo R. Role of saliva in the maintenance of taste sensitivity. Crit Rev Oral Biol Med. 2000;11:216-29.

7. Tabak LA, Levine MJ, Mandel ID, Ellison SA. Role of salivary mucins in the protection of the oral cavity. J Oral Pathol. 1982;11:1-17.

8. Blasco PA, Allaire JH. Drooling in the developmentally disabled: management practices and recommendations. Consortium on Drooling. Dev Med Child Neurol. 1992;34:849-62.

9. van Hulst K, van den Engel-Hoek L, Geurts ACH, et al. Development of the Drooling Infants and Preschoolers Scale (DRIPS) and reference charts for monitoring saliva control in children aged 0-4 years. Infant Behav Dev. 2018;50:247-56.
10. Verma R, Anand KS. Botulinum toxin: a novel therapy for clozapine-induced sialorrhoea. Psychopharmacology. 2018;235:369-71.

11. Camp-Bruno JA, Winsberg BG, Green-Parsons AR, Abrams JP. Efficacy of benztropine therapy for drooling. Dev Med Child Neurol. 1989;31:309-19.

12. Crysdale WS, White A. Submandibular duct relocation for drooling: a 10-year experience with 194 patients. Otolaryngol Head Neck Surg. 1989;101:87-92.

13. Thomas-Stonell N, Greenberg J. Three treatment approaches and clinical factors in the reduction of drooling. Dysphagia. 1988;3:73-8.

14. Blasco PA. Management of drooling: 10 years after the Consortium on Drooling, 1990. Dev Med Child Neurol. 2002;44:778-81.

15. Ellies M, Rohrbach-Volland S, Arglebe C, Wilken B, Laskawi R, Hanefeld F. Successful management of drooling with botulinum toxin A in neurologically disabled children. Neuropediatrics. 2002;33:327-30.

16. Crysdale WS, McCann C, Roske L, Joseph M, Semenuk D, Chait P. Saliva control issues in the neurologically challenged. A 30 year experience in team management. Int J Pediatr Otorhinolaryngol. 2006;70:519-27.

17. Steffen A, Ortfeld S, Schönweiler R. Drooling bei neuropädiatrischen Patienten-ein Update. Klin Pädiatr. 2011;223:5-9.

18. Bartolome G. Aspirationsschnelltests und Klinische Schluckuntersuchung. In: Bartolome G, SchröterMorasch H, editors. Schluckstörungen-Diagnostik und Rehabilitation. 5. Munich: Elsevier; 2014.

19. Langmore SE, Schatz K, Olsen N. Fiberoptic endoscopic examination of swallowing safety: a new procedure. Dysphagia. 1988;2:216-9.

20. Schröter-Morasch H, Graf S. Dysphagiediagnostik durch den HNO-Arzt. HNO. 2014;62:324-34.

21. Murray J, Langmore SE, Ginsberg S, Dostie A. The significance of accumulated oropharyngeal secretions and swallowing frequency in predicting aspiration. Dysphagia. 1996;11:99-103.

22. Reynolds J, Carroll S, Sturdivant C. Fiberoptic endoscopic evaluation of swallowing: a multidisciplinary alternative for assessment of infants with dysphagia in the neonatal intensive care unit. Adv Neonatal Care. 2016;16:37-43.

23. Diesener P. Schluckstörungen bei Kindern: Bildgebende Diagnostik mittels transnasaler Videoendoskopie. Prakt Pädiatrie. 1999;5:36-42. 
24. Bader C, Niemann G. Dysphagie bei Kindern mit Infantiler Zerebralparese-Fiberoptisch -endoskopische Befunde. Laryngorhinootologie. 2010;89:90-4.

25. Rohrbach S, Gross M. Die transnasale fiberoptischendoskopische Schluckuntersuchung (FEES) bei Kindern-Standardisiertes diagnostisches Vorgehen. Monatsschrift Kinderheilkunde. 2014;162:329-33.

26. Holzapfel K. Radiologische Diagnostik. In: Bartolome G, Schröter-Morasch $\mathrm{H}$, editors. Schluckstörungen-Diagnostik und Rehabilitation. 5th ed. Munich: Elsevier; 2014.

27. Olthoff A, Carstens PO, Zhang S, et al. Evaluation of dysphagia by novel real-time MRI. Neurology. 2016;87:2132-8.

28. Olthoff A, Joseph AA, Weidenmüller M, Riley B, Frahm J. Real-time MRI of swallowing: intraoral pressure reduction supports larynx elevation. NMR Biomed. 2016;29:1618-23.

29. Bartolome G. Grundlagen der funktionellen Dysphagietherapie (FDT). In: Bartolome G, Schröter-Morasch $\mathrm{H}$, editors. Schluckstörungen-Diagnostik und Rehabilitation. Munich-Jena: Urban \& Fischer; 2010. p. 245-370.

30. Hinchey JA, Shephard T, Furie K, et al. Formal dysphagia screening protocols prevent pneumonia. Stroke. 2005;36:1972-6.

31. Carnaby G, Hankey GJ, Pizzi J. Behavioural intervention for dysphagia in acute stroke: a randomised controlled trial. Lancet Neurol. 2006;5:31-7.

32. Prosiegel M, Bartolome G, Biniek R, et al. Rehabilitation neurogener Dysphagien. In: Diener HC, editor. Leitlinien für Diagnostik und Therapie in der Neurologie. Stuttgart: Thieme; 2008. p. 908-19.

33. Mikami DLY, Furia CLB, Welker AF. Addition of kinesio taping of the orbicularis oris muscles to speech therapy rapidly improves drooling in children with neurological disorders. Dev Neurorehabil. 2017;21:1-6.

34. Hussein I, Kershaw AE, Tahmassebi JF, Fayle SA. The management of drooling in children and patients with mental and physical disabilities: a literature review. Int J Paediatr Dent. 1998;8:3-11.

35. Limbrock GJ, Hoyer H, Scheying H. Drooling, chewing and swallowing dysfunctions in children with cerebral palsy: treatment according to CastilloMorales. ASDC J Dent Child. 1990;57:445-51.

36. De Simone GG, Eisenchlas JH, Junin M, Pereyra F, Brizuela R. Atropine drops for drooling: a randomized controlled trial. Palliat Med. 2006;20:665-71.
37. Hyson HC, Johnson AM, Jog MS. Sublingual atropine for sialorrhea secondary to parkinsonism: a pilot study. Mov Disord. 2002;17:1318-20.

38. Matos Santana TE, Capurso NA, Ranganathan M, Yoon G. Sublingual atropine in the treatment of clozapine-induced sialorrhea. Schizophr Res. 2017;182:144-5.

39. Fischbacher L, Schröter-Morasch H. Medikamentöse Speichelreduktion bei Neurogener Dysphagie. In: Gross M, Kruse E, editors. Aktuelle phoniatrischepädaudiologische Aspekte 2003/2004 Band 11, Medicombooks.de im Verlag videel, Niebüll.

40. Blasco PA, Stansbury JC. Glycopyrrolate treatment of chronic drooling. Arch Pediatr Adolesc Med. 1996;150:932-5.

41. Bachrach SJ, Walter RS, Trzcinski K. Use of glycopyrrolate and other anticholinergic medications for sialorrhea in children with cerebral palsy. Clin Pediatr (Phila). 1998;37:485-90.

42. Mier RJ, Bachrach SJ, Lakin RC, Barker T, Childs J, Moran M. Treatment of sialorrhea with glycopyrrolate: a double-blind, dose-ranging study. Arch Pediatr Adolesc Med. 2000;154:1214-8.

43. Man WH, Colen-de Koning JC, Schulte PF, et al. The effect of glycopyrrolate on nocturnal sialorrhea in patients using clozapine: a randomized, crossover, double-blind, placebo-controlled trial. J Clin Psychopharmacol. 2017;37:155-61.

44. Blissit KT, Tillery E, Latham C, Pacheco-Perez J. Glycopyrrolate for treatment of clozapine-induced sialorrhea in adults. Am J Health Syst Pharm. 2014;71:1282-7.

45. Lee ZI, Yu KJ, Lee DH, et al. The effect of nebulized glycopyrrolate on posterior drooling in patients with brain injury: two cases of different brain lesions. Am J Phys Med Rehabil. 2017;96:e155-8.

46. Praharaj SK, Munoli RN, Sharma PS. Low-dose glycopyrrolate for clozapine-associated sialorrhea. J Clin Psychopharmacol. 2014;34:392.

47. Banfi P, Ticozzi N, Lax A, Guidugli GA, Nicolini A, Silani V. A review of options for treating sialorrhea in amyotrophic lateral sclerosis. Respir Care. 2015;60:446-54.

48. Qurashi I, Chu S, Husain N, Drake RJ, Chaudhry I, Deakin JF. Glycopyrrolate in comparison to hyoscine hydrobromide and placebo in the treatment of hypersalivation induced by clozapine (GOTHIC1): study protocol for a randomised controlled feasibility study. Trials. 2016;17:553. 
49. Parr JR, Weldon E, Pennington L, et al. The drooling reduction intervention trial (DRI): a single blind trial comparing the efficacy of glycopyrronium and hyoscine on drooling in children with neurodisability. Trials. 2014;15:60.

50. Zeller RS, Davidson J, Lee HM, Cavanaugh PF. Safety and efficacy of glycopyrrolate oral solution for management of pathologic drooling in pediatric patients with cerebral palsy and other neurologic conditions. Ther Clin Risk Manag. 2012;8:25-32.

51. Zeller RS, Lee HM, Cavanaugh PF, Davidson J. Randomized phase III evaluation of the efficacy and safety of a novel glycopyrrolate oral solution for the management of chronic severe drooling in children with cerebral palsy or other neurologic conditions. Ther Clin Risk Manag. 2012;8:15-23.

52. Uppal HS, De R, D'Souza AR, Pearman K, Proops DW. Bilateral submandibular duct relocation for drooling: an evaluation of results for the Birmingham Children's Hospital. Eur Arch Otorhinolaryngo. 2003;260:48-51.

53. Katona G, Csákányi Z, Lorincz A, Gerlinger I. Bilateral submandibular duct relocation by highfrequency radiosurgery. Eur Arch Otorhinolaryngol. 2008;265:1103-8.

54. Mankarious LA, Bottrill ID, Huchzermeyer PM, Bailey CM. Long-term follow-up of submandibular duct rerouting for the treatment of sialorrhea in the pediatric population. Otolaryngol Head Neck Surg. 1999;120:303-7.

55. Martin TJ, Conley SF. Long-term efficacy of intraoral surgery for sialorrhea. Otolaryngol Head Neck Surg. 2007;137:54-8.

56. Reed J, Mans CK, Brietzke SE. Surgical management of drooling: a meta-analysis. Arch Otolaryngol Head Neck Surg. 2009;135:924-31.

57. Becmeur F, Schneider A, Flaum V, Klipfel C, Pierrel $C$, Lacreuse I. Which surgery for drooling in patients with cerebral palsy? J Pediatr Surg. 2013;48:2171-4.

58. Formeister EJ, Dahl JP, Rose AS. Surgical management of chronic sialorrhea in pediatric patients: 10-year experience from one tertiary care institution. Int J Pediatr Otorhinolaryngol. 2014;78:1387-92.

59. Noonan K, Prunty S, Ha JF, Vijayasekaran S. Surgical management of chronic salivary aspiration. Int J Pediatr Otorhinolaryngol. 2014;78:2079-82.

60. Kok SE, van der Burg JJ, van Hulst K, Erasmus CE, van den Hoogen FJ. The impact of submandibular duct relocation on drooling and the well-being of children with neurodevelopmental disabilities. Int J Pediatr Otorhinolaryngol. 2016;88:173-8.

61. Feussner H, Schröter-Morasch H. Chirurgische Interventionen bei Schluckstörungen. In: Bartolome $\mathrm{G}$, Schröter-Morasch $\mathrm{H}$, editors. Schluckstörungen-Diagnostik und Rehabilitation. 5th ed. Munich: Elsevier; 2014.

62. Lawson G, Remacle M. Endoscopic cricopharyngeal myotomy: indications and technique. Curr Opin Otolaryngol Head Neck Surg. 2006;14:437-41.

63. Seegenschmiedt MH, Makoski HB, Trott KR, Brady LW. Sialorrhea/Hypersalivation. In: Seegenschmiedt MH, Makoski HB, Trott KR, Brady LW, editors. Radiotherapy for non-malignant disorders. Berlin: Springer; 2008. p. 573-579.

64. Andersen PM, Grönberg H, Franzen L, Funegård U. External radiation of the parotid glands significantly reduces drooling in patients with motor neuron disease with bulbar paresis. J Neurol Sci. 2001;191:111-4.

65. Borg M, Hirst F. The role of radiation therapy in the management of sialorrhea. Int J Radiat Oncol Biol Phys. 1998;41:1113-9.

66. Neppelberg E, Haugen DF, Thorsen L, Tysnes OB. Radiotherapy reduces sialorrhea in amyotrophic lateral sclerosis. Eur J Neurol. 2007;14:1373-7.

67. Postma AG, Heesters M, van Laar T. Radiotherapy to the salivary glands as treatment of sialorrhea in patients with parkinsonism. Mov Disord. 2007;22:2430-5.

68. Assouline A, Levy A, Abdelnour-Mallet $M$, et al. Radiation therapy for hypersalivation: a prospective study in 50 amyotrophic lateral sclerosis patients. Int J Radiat Oncol Biol Phys. 2014;88:589-95.

69. Weikamp JG, Schinagl DA, Verstappen CC, Schelhaas HJ, de Swart BJ, Kalf JG. Botulinum toxin-A injections vs. radiotherapy for drooling in ALS. Acta Neurol Scand. 2016;134:224-31.

70. Hawkey NM, Zaorsky NG, Galloway TJ. The role of radiation therapy in the management of sialorrhea: a systematic review. Laryngoscope. 2016;126:80-5.

71. Steffen A, Wollenberg B, Schönweiler R, Brüggemann N, Meyners T. Drooling nach Strahlentherapie-Botulinumtoxin als erfolgreiches Therapieverfahren. HNO. 2011;59:115-7.

72. Christiansen H, Wolff HA, Knauth J, et al. Radiotherapy: an option for refractory salivary fistulas. HNO. 2009;57:1325-8. 
73. Xu H, Shan XF, Cong X, et al. Pre- and post-synaptic effects of botulinum toxin A on submandibular glands. J Dent Res. 2015;94:1454-62.

74. Bushara KO. Sialorrhea in amyotrophic lateral sclerosis: a hypothesis of a new treatment-botulinum toxin A injections of the parotid glands. Med Hypotheses. 1997;48:337-9.

75. Bhatia KP, Münchau A, Brown P. Botulinum toxin is a useful treatment in excessive drooling in saliva. J Neurol Neurosurg Psychiatry. 1999;67:697.

76. Jost WH. Treatment of drooling in Parkinson's disease with botulinum toxin. Mov Disord. 1999;14:1057.

77. Chaléat-Valayer E, Porte M, Buchet-Poyau K, et al. Management of drooling in children with cerebral palsy: a French survey. Eur J Paediatr Neurol. 2016;20:524-31.

78. Egevad G, Petkova VY, Vilholm OJ. Sialorrhea in patients with Parkinson's disease: safety and administration of botulinum neurotoxin. J Parkinsons Dis. 2014;4:321-6.

79. Ko SH, Shin YB, Min JH, et al. Botulinum toxin in the treatment of drooling in tetraplegic patients with brain injury. Ann Rehabil Med. 2013;37:796-803.

80. Mancini F, Zangaglia R, Cristina S, et al. Doubleblind, placebo-controlled study to evaluate the efficacy and safety of botulinum toxin type A in the treatment of drooling in parkinsonism. Mov Disord. 2003;18:685-8.

81. Martínez-Poles J, Nedkova-Hristova V, EscribanoParedes JB, et al. Incobotulinumtoxin A for sialorrhea in neurological disorders: a real-life experience. Toxins (Basel). 2018;28:10.

82. Narayanaswami P, Geisbush T, Tarulli A, et al. Drooling in Parkinson's disease: a randomized controlled trial of incobotulinum toxin A and metaanalysis of Botulinum toxins. Parkinsonism Relat Disord. 2016;30:73-7.

83. Restivo DA, Panebianco M, Casabona A, et al. Botulinum toxin A for sialorrhoea associated with neurological disorders: evaluation of the relationship between effect of treatment and the number of glands treated. Toxins (Basel). 2018;10.

84. Stokholm MG, Bisgård C, Vilholm OJ. Safety and administration of treatment with botulinum neurotoxin for sialorrhoea in ALS patients: review of the literature and a proposal for tailored treatment. Amyotroph Lateral Scler Frontotemporal Degener. 2013;14:516-20.
85. Giess R, Naumann M, Werner E, et al. Injections of botulinum toxin A into the salivary glands improve sialorrhoea in amyotrophic lateral sclerosis. J Neurol Neurosurg Psychiatry. 2000;69:121-3.

86. Mazlan M, Rajasegaran S, Engkasan JP, Nawawi O, Goh KJ, Freddy SJ. A double-blind randomized controlled trial investigating the most efficacious dose of botulinum toxin-A for sialorrhea treatment in Asian adults with neurological diseases. Toxins (Basel). 2015;7:3758-70.

87. Ondo WG, Hunter C, Moore W. A double-blind placebo-controlled trial of botulinum toxin B for sialorrhea in Parkinson's disease. Neurology. 2004;62:37-40.

88. Chinnapongse R, Gullo K, Nemeth P, Zhang Y, Griggs L. Safety and efficacy of botulinum toxin type B for treatment of sialorrhea in Parkinson's disease: a prospective double-blind trial. Mov Disord. 2012;27:219-26.

89. Guidubaldi A, Fasano A, Ialongo T, et al. Botulinum toxin $A$ versus $B$ in sialorrhea: a prospective, randomized, double-blind, crossover pilot study in patients with amyotrophic lateral sclerosis or Parkinson's disease. Mov Disord. 2011;26:313-9.

90. Jackson CE, Gronseth G, Rosenfeld J, et al. Randomized double-blind study of botulinum toxin type B for sialorrhea in ALS patients. Muscle Nerve. 2009;39:137-43.

91. Lagalla G, Millevolte M, Capecci M, Provinciali L, Ceravolo MG. Botulinum toxin type A for drooling in Parkinson's disease: a double-blind, randomized, placebo-controlled study. Mov Disord. 2006;5:704-7.

92. Lagalla G, Millevolte M, Capecci M, Provinciali L, Ceravolo MG. Long-lasting benefits of botulinum toxin type B in Parkinson's disease-related drooling. J Neurol. 2009;256:563-7.

93. Lipp A, Trottenberg T, Schink T, Kupsch A, Arnold G. A randomized trial of botulinum toxin A for treatment of drooling. Neurology. 2003;61:1279-81.

94. Reid SM, Johnstone BR, Westbury C, Rawicki B, Reddihough DS. Randomized trial of botulinum toxin injections into the salivary glands to reduce drooling in children with neurological disorders. Dev Med Child Neurol. 2008;50:123-8.

95. Dashtipour K, Bhidayasiri R, Chen JJ, Jabbari B, Lew M, Torres-Russotto D. RimabotulinumtoxinB in sialorrhea: systematic review of clinical trials. J Clin Mov Disord. 2017;6(4):9. https://doi.org/10.1186/ s40734-017-0055-1. 
96. George KS, Kiani H, Witherow H. Effectiveness of botulinum toxin B in the treatment of drooling. Br J Oral Maxillofac Surg. 2013;51:783-5.

97. Winterholler MG, Erbguth FJ, Wolf S, Kat S. Botulinum toxin for the treatment of sialorrhoea in ALS: serious side effects of a transductal approach. J Neurol Neurosurg Psychiatry. 2001;70:417-8.

98. Dogu O, Apaydin D, Sevim S, Talas DU, Aral M. Ultrasound-guided versus 'blind' intraparotid injections of botulinum toxin-A for the treatment of sialorrhoea in patients with Parkinson's disease. Clin Neurol Neurosurg. 2004;106:93-6.

99. Pagan F, Jost WH, Michel O, et al. Long-term efficacy and safety of incobotulinumtoxinA treatment for sialorrhea. Toxicon 2018;156:S86-7.

100. Ono K, Morimoto Y, Inoue H, Masuda W, Tanaka T, Inenaga K. Relationship of the unstimulated whole saliva flow rate and salivary gland size estimated by magnetic resonance image in healthy young humans. Arch Oral Biol. 2006;51:345-9.

101. Scott J. Age, sex and contralateral differences in the volumes of human submandibular salivary glands. Arch Oral Biol. 1975;20:885-7.
102. So JI, Song DH, Park JH, et al. Accuracy of ultrasound-guided and non-ultrasound-guided botulinum toxin injection into cadaver salivary glands. Ann Rehab Med. 2017;41:51-7.

103. Steffen A, Jost W, Bäumer T, et al. Hypersalivation: update of the German S2 k guideline (AWMF) in short form. J Neural Transm (Vienna). 2019;126:853-62.

104. Srivanitchapoom P, Pandey S, Hallett M. Drooling in Parkinson's disease: a review. Parkinsonism Rel Disord. 2014;20:1109-18.

105. McGeachan AJ, McDermott CJ. Management of oral secretions in neurological disease. Pract Neurol. 2017;17:96-103.

106. Ruiz-Roca JA, Pons-Fuster E, Lopez-Jornet P. Effectiveness of the botulinum toxin for treating sialorrhea in patients with Parkinson's disease: a systematic review. J Clin Med. 2019. https://doi. org/10.3390/jcm8030317.

107. Steinlechner S, Klein C, Moser A, Lencer R, Hagenah J. Botulinum toxin B as an effective and safe treatment for neuroleptic-induced sialorrhea. Psychopharmacology. 2010;207:593-7. 